\title{
Voicing young and older adult care-leavers in Belgium: How the experience of being in care shapes narratives of the self
}

\author{
Ilse Luyten* Vrije Universiteit Brussel, Belgium \\ An Nuytiens* Vrije Universiteit Brussel, Belgium \\ an.nuytiens@vub.be \\ Jenneke Christiaens Vrije Universiteit Brussel, Belgium \\ Els Dumortier Vrije Universiteit Brussel, Belgium
}

$\left({ }^{*}\right)$ shared first authors

(Received Feb 2017 Revised December 2017)

http://dx.doi.org/10.14301/llcs.v9i1.456

\begin{abstract}
This article draws on a study of 38 male and female care-leavers in Belgium (age 21-66 years). Life history interviews were conducted to investigate how they experienced being in care, how they perceived the impact of this on their later life course, and how they reflected on shifts in their narratives as their lives progressed. The results shed light on the subjective impact of being in care on the lives of care-leavers. The interviews reveal three narratives of the self, shaped by the experience of being in care: the collective self, the problematic self and the resilient self. The collective self and the problematic self engender feelings of stigmatisation and a search for the lost self or new self throughout the subsequent life course. Because the impact of being in care on narratives of the self change over time, a long-term perspective is needed. Our research reveals the importance of a subjective view on adult outcomes. To enhance the wellbeing of care-leavers and to contribute to positive development of the self, policy, practice and research should pay more attention to internal and subjective processes of care-leavers in youth care. The results reveal similarities with processes described in the desistance literature, suggesting new research opportunities.
\end{abstract}

\section{Keywords}

Narratives of the self; care-leavers; life history research 


\section{Introduction}

The last decade has seen a growing interest in the adult outcomes of care-leavers in the criminological literature and beyond (Carr \& McAlister, 2016). This growing body of research explores how care-leavers fare after leaving the care setting. As focus is often on the phase of 'leaving care', most findings draw on data gathered from young adults. From the literature, it appears that care-leavers are at risk of an unsuccessful transition to adulthood. Measurement of classic markers of societal 'success' in populations of careleavers has revealed that they often experience problems in several life domains. While these studies focus on so-called 'objective' factors, we take a subjective perspective. By exploring narratives of the self, gathered by life history interviews with young and older care-leavers, we aim at a qualitative understanding of the subjective and long-term impact of being in care on the later life course.

In this contribution we first provide an overview of the literature concerning care-leavers' adult outcomes and narratives of the self. In the following paragraphs we describe our research method and the research findings. Finally, the most important results are reviewed in the discussion and conclusion section.

\section{Literature review}

\section{Adult outcomes of care-leavers: a story of problems?}

Recently, the body of research scrutinising careleavers' adult outcomes has increased substantially. For example, in 2011, a thematic issue of Children and Youth Services Review was published ('Young People's Transitions from Care to Adulthood'), and in 2014 Australian Social Work published a special issue titled 'Young People Transitioning from Outof-home Care: An Issue of Social Justice'. More recently, an international edited volume, Young People Transitioning from Out-of-Home Care: International Research, Policy and Practice, was released (Mendes \& Snow, 2016).

In this body of literature, care is often specified as out-of-home care, which includes any setting where children are not raised by their parents (e.g. foster care, kinship care, residential settings). Therefore, the concept of 'care-leaver' may cover different groups of people who spent (a part of) their childhood in one or more of these care settings. Despite the different conceptualisations of 'care-leaver', these studies have repeatedly shown that care-leavers are likely to have an unsuccessful transition to adulthood as they experience problems in several life domains, often intertwined. Overall, they seem to run a higher risk of being socially excluded and of having a reduced quality of life (Van Audenhove \& Vander Laenen, 2011). While ageing out of care, they often feel isolated due to the lack of a steady network, including a partner, family and friends. Also, they encounter problems in finding an affordable and stable place to live, which for some leads to homelessness. Research reveals that almost a third of the homeless population experienced one or more episodes of youth care (Stas, Serrien \& Van Menxel, 2008; Van Menxel, Lescrauwaet \& Parys, 2003). Care-leavers often have a low level of educational attainment or fail to achieve a degree after leaving care (Courtney, Piliavin, Grogan-Kaylor, \& Nesmith, 2001; Dumaret, Donati, \& Crost, 2011; Reilly, 2003; Zeira, Arzev, Benbenishty \& Portnoy, 2014), resulting in problems in finding a good and well-paid job. Consequently, many care-leavers deal with financial problems and poverty, with about one in three care-leavers in debt (Barth, 1990; Courtney et al., 2001; van der Geest, Bijleveld, \& Verbruggen, 2013).

Research has revealed more mental problems in populations of care-leavers in comparison with the general population. This may be explained by traumatic childhoods and the experience of being in youth care. Mental problems, such as depression, sleep disorder, borderline personality disorder, schizophrenia, autism and bipolar disorder, are found to be linked to trauma and youth care (Barth, 1990; McCord, 2002; van der Geest et al., 2013). Many care-leavers have used alcohol and/or drugs excessively starting from childhood or adolescence (Barth, 1990; Felitti, 2002; van der Geest et al., 2013; Vander Laenen, 2008), often as a result of trauma. People experiencing trauma may use alcohol and/or drugs to forget or process traumatic events (McClellan, Farabee \& Crouch, 1997). This may be especially true for female victims of physical and sexual abuse (Maeve, 2000; McClellan et al., 1997). Also, mental problems such as depression may lead to self-medication in order to cope with these negative feelings (see e.g. Sheridan, 1996). 
Besides mental problems, care-leavers seem to experience elevated levels of physical complications such as dental problems. It appears that, because of financial problems, regular medical check-ups are often skipped or postponed (Barth, 1990; Courtney et al., 2001; McCord, 1978). The prevalence of teenage pregnancy is also higher in comparison with the general population (Bloom, Owen, Rosenbaum, \& Deschenes, 2003; Polit, Morton, \& White, 1989).

Finally, care-leavers are often found to have relatively high offending rates in adulthood (see e.g. Gatti, Tremblay, \& Vitaro, 2009; McCord, 2002; Verbruggen, Apel, van der Geest \& Blokland, 2015). They are more at risk of committing offences as an adult than adults without a history of being in care (Zeira et al., 2014).

Although the above-mentioned studies clearly indicate that care-leavers do not tend to fare well as adults, and often fare less well than their counterparts who haven't been in care, we need to be critical since this body of research often focuses on the measurement of standard markers of 'success' or 'inclusion/integration' in society: housing, grades, (un)employment, criminal justice involvement, etc. By doing so, attention is directed to the outer life indicators of care-leavers; on socalled 'objectifiable' factors representing stability or change (e.g. losing a job, giving birth) in the lives of care-leavers. Besides, these studies mainly focus on young adults who find themselves in the middle of or just after the phase of 'leaving care'. This means that most youngsters involved in these studies are going through the phase of emerging adulthood, a transition period characterised by instability as such. Arnett $(2007,152)$ defines emerging adulthood as "the age of identity explorations, the age of instability, the self-focused age, the age of feeling in-between, and the age of possibilities". Consequently, a 'story of problems' in which careleavers "are often depict[ed] ... as a vulnerable group" (Höjer \& Sjöblom, 2014, p. 73) is recycled again and again.

\section{Care-leavers' narratives of the self}

In research on adult outcomes of care-leavers, far less attention is paid to internal factors, reflections on the care experience and its aftermath. For example, the lack of information about family and cultural heritage makes it difficult to answer the question "Who am I?" (Goddard, Murray, \& Duncalf, 2013; Murray, 2015). Care- leavers are supposed to enter adulthood suddenly, adjust very quickly to a new context and cope with their new adult role (Nuytiens \& Geluyckens, 2015; Stein, Ward, \& Courtney, 2011). Dima and Skehill (2011) refer to this as the expectation of 'instant adulthood'. However, care-leavers must also come to terms subjectively with their new situation (Dima \& Skehill, 2011, p. 2537). Overall, limited research attention has been directed to the long-term development of the self and identity of care-leavers (Dima \& Skehill, 2011, p. 2534). Research on how narratives of the self evolve in relation to the experience of being in care remains scarce. The present study contributes to the qualitative understanding of the subjective impact of being in care on narratives of the self and one's life. How a care-leaver experiences the past and his/her current life situation does not only depend on outer markers, but is also affected by how a person experienced and interpreted care. This subjective understanding of care is reflected in narratives during the subsequent life course.

In an attempt to fill this gap in the literature, this article focuses on how care-leavers narrate about the self. Drawing on life-history interviews with care-leavers of different ages we explore how their narratives of the self develop in relation to their experience of being in care. We bring to the fore central questions: how do care-leavers themselves perceive, understand and explain past experiences in care (over time)? In what ways do they understand how these experiences have affected who they have become? In doing so, we gain insight into how self-perception is shaped by the out-ofhome care experience, and how this evolves over time.

This study is the first in Belgium to explore the experiences and perceptions of care-leavers themselves from a long-term perspective. Research on adult outcomes of care-leavers mainly focuses on short-term outcomes. Studies focus on youngsters who are still in the system (see e.g. Delens-Ravier, 2005), or in the phase of 'leaving care' (see e.g. Van Audenhove, 2015). Consequently this body of research involves juveniles or young adults. However, research on the actual impact of growing up in care requires a long-term perspective. Because care-leavers often go through a 'survival period' before moving to a more stable life situation, differences between adult careleavers and other adults diminish as they age 
(Duncalf, 2010; Frechon \& Dumaret, 2008). For this reason we looked beyond emerging adulthood and included participants in a broad age range.

While this article is centred on care-leavers' narratives of the self, this was not the point of departure of the study. The life history interviews with care-leavers were conducted to shed light on the lives before, during and after being placed in care, and more specifically to investigate inductively how being in care has, according to care-leavers themselves, affected their later life course. The aim was not to depict reality or the truth ('fact-finding') but rather the construction of reality (see e.g. Flick, 2004) by the care-leavers. Thus, we sought to 'give voice' to adult care-leavers. We tried to capture the subjectivity of how care-leavers have experienced this period in their life, and how this experience has impacted their later life course. Therefore we focus on the 'experience as told' (Larkin, Watts, \& Clifton, 2006). Participants reflected a lot about the question "Who am I?" Consequently, the topic of 'the self' emerged as an important theme in their narratives.

We conceptualise the self from a social constructionist perspective, which suggests that a person consists of multiple selves embedded in a sociocultural and historical context (Lincoln \& Guba, 2003). The view of self as an individual and as a group member is shaped by societal discourses. By including participants from different age groups, we will be able to gain insight into whether and how the societal context impacts experiences of care and self-narratives. Interpersonal expectations also shape peoples' life stories (Pasupathi, 2001). People construct and reconstruct their selves in relation to other people and cannot be understood apart from one another (Abrams, 2010; Bruner, 2004; Pasupathi, 2001; Sermijn, Loots, \& Devlieger, 2005). The way we look at ourselves and our experiences is likewise dependent on social roles and patterns. When these roles change throughout our lives, the story about ourselves may also change (Abrams, 2010; Apfelbaum, 2010). When care-leavers leave care and move from 'youngsters in care' to 'careleavers', this transition is likely to impact their selfnarratives.

While the self is shaped by the social context, it is not merely reflective of external influences. Although people are confronted with (institutionally based) power, the self may still be considered as an 'agent' or reflexive actor who, apart from influence by the context, makes choices (Callero, 2003; Rowe, 2011). Our research results support this insight; in the self-narratives a resilient self (being agentic and resistant within a restrictive context of control) emerged. The multiple self has the ability to choose one, albeit temporary, coherent story, of which the content can be adapted any time (Bruner, 2004; Sermijn, 2008; Sermijn et al., 2005). The stories do not only describe experiences from the past, but also provide ways to give a temporary and coherent meaning to these experiences (Miyahara, 2010). Through self-presentation, the self participates in life and in doing so communicates and performs some information about itself to others (Baumeister, 1998). In that sense, the story we heard during the interviews is not 'the' story. What we heard was one 'entrée' to our participants' life stories.

\section{Methods}

\section{Research questions}

This research explored long-term adult outcomes of care-leavers in Flanders (the Dutchspeaking part of Belgium). Life history interviews with 38 care-leavers (21-66 years old) were conducted by the first shared author to investigate three questions:

1) How do care-leavers narrate the experience of being in care?

2) How do care-leavers perceive the impact of being in care on their lives?

3) How do they reflect on how this narrative about being in care and its impact - shifted as their lives progressed?

\section{The sample}

We defined care-leavers as people who had been in out-of-home care as a minor.

Our sample was a convenience sample of 14 men and 24 women and may not be representative for all care-leavers in Flanders/Belgium. Representativeness was, however, not the aim of our qualitative study. Participants were mainly recruited through advocacy groups $(n=19)$. Social work and welfare institutions helped us to find nine other participants. The advocacy groups and social welfare institutions contacted our participants. We also reached six care-leavers through friends, family and colleagues. One participant was recruited by snowball sampling, and was first contacted by our initial participant. Social media was a less successful strategy in our search for participants $(n=3)$. 
Participants were born between 1949 and 1994, and aged between 21 and 66 years at the time of the interview, with an average of 37.7 years (median: 37.5 years). As table 1 shows, a substantial part of the sample was 21 and 30 years old $(n=12)$ or between 31 and $40(n=12)$ at the time of the interview. However, people in their forties $(n=8)$ are also well represented. Only six participants were older than 50.

For each participant, we counted every stay in an institution. As we did not consult the official case files, the participants provided information about the number of institutions in which they were placed, the duration of their stays and the reason for placement.

As care-leavers often resided in more than one institution, the number of the stays is larger than the sample. Participants were mostly placed in institutions: orphanages $(n=2), \quad$ (children's) psychiatric centres $(n=4)$, public youth care centres $(n=11)$ or private youth care centres $(n=48)$. While in public centres, both juvenile victims and offenders are detained, in private centres mainly juvenile victims are placed. While in practice, the line between juvenile victims and offenders appears to be quite blurred (Dumortier, Christiaens \& Nuytiens, 2017), and the distinction is rather artificial, being in one or another type of centre might impact how the care-leavers experienced their stay, as there are important differences. For example: public centres are perceived to have more restricted rules and may be completely closed regimes. We also counted several placements in foster care $(n=9)$. Note that not everyone could remember the exact type of out-of-home care. In that case the authors used the information in the interviews to deduce which type of care they probably stayed in. While being in foster care always meant being in a foster family for our participants, we also consider this as out-of-home care, as it meant being removed from home.

Some participants stayed in care for a short period of time, while others stayed there for the remainder of their childhood. The average number of years in out-of-home care was eight years (median: 6 years). As shown in table 2, most of the care-leavers spent one to five years in out-of-home care. Everyone but two of this group entered care as a teenager and resided in care until his or her 18th or 21st birthday. The age of majority today is 18 in Belgium (before 1990 it was 21) and the youth care intervention normally ends at age 18 . However, youngsters in care may (under certain conditions) request a prolongation of the intervention. Before 2014 the intervention could be prolonged until the age of 21 in Flanders. With the recent Flemish Decree on Integrated Youth Care (2013) the prolongation of the intervention was raised to 25 .

Table 1. Gender and age of participants.

\begin{tabular}{|l|l|}
\hline Gender & N \\
\hline Male & 14 \\
\hline Female & 24 \\
\hline Age & N \\
\hline $21-25$ & 8 \\
\hline $26-30$ & 4 \\
\hline $31-35$ & 5 \\
\hline $36-40$ & 7 \\
\hline $41-45$ & 4 \\
\hline $46-50$ & 4 \\
\hline $51-55$ & 3 \\
\hline $56-60$ & 2 \\
\hline $61-65$ & 0 \\
\hline $66-70$ & 1 \\
\hline
\end{tabular}


Table 2. Duration of stay in out-of-home care.

\begin{tabular}{|l|l|}
\hline Years in out-of-home care & N \\
\hline $1-5$ & 17 \\
\hline $6-10$ & 9 \\
\hline $11-15$ & 5 \\
\hline $16-21$ & 7 \\
\hline
\end{tabular}

Table 3. Reasons for being sent to care

\begin{tabular}{|l|l|l|l|}
\hline & \multicolumn{2}{|l|}{ Gender } & \\
\hline $\begin{array}{l}\text { Reason } \\
\text { (according to the narratives) }\end{array}$ & $\mathrm{M}$ & $\mathrm{F}$ & Total \\
\hline Problems at home & 9 & 21 & 30 \\
\hline Delinquency & 3 & 0 & 3 \\
\hline Both & 2 & 3 & 5 \\
\hline Total & 14 & 24 & 38 \\
\hline
\end{tabular}

All participants said they were sent to out-ofhome care as a result of an intervention of the Belgian youth protection system (see table 3 ). This could be the Youth Court and/or other youth care services. Most of them $(n=30)$ mentioned they were placed in care due to problems at home: abuse (sexual, physical and/or emotional), neglect, drug/alcohol dependency of the parents, psychiatric problems of the parents or a turbulent divorce. Two women were placed out of home because they, aged between 12 and 14, had a relationship with (and in one case was pregnant by) an adult man. Three participants mentioned (adolescent or adult) delinquent behaviour in their narratives. The Youth Court sent them to an institution because of drug use and thefts/robberies. Two of these three mentioned serious problems such as abuse or violence at their home, and perceived these problems as the reason for staying out late and engaging in delinquent behaviour. The remaining five participants said they entered the youth protection system for both reasons (first due to problems at home and afterwards due to offending behaviour, or the other way around).

\section{Data collection}

The interviews were conducted in two sweeps: December 2013 - July 2014 (15 participants) and January 2015 - January 2016 (23 participants). As participants could choose the location of the interview, this was mainly at their homes or at their local pub or a relief centre. Participants signed an informed consent form to formalise anonymity, voluntariness and recordings. Three participants refused the recording of the interview.

Before the interview every participant received information (by phone and by email) about the research. All participants orally consented. While we always aimed at also receiving a written informed consent this was not always the case. Due to negative contacts with authorities, some careleavers were reluctant to sign our document. Others read the information, but said they trusted the researcher and were not willing to sign the document, as they did not think this was necessary. A few already started the conversation before the researcher could introduce the written consent form. In these occasions we had the feeling that constraining participants to sign the document after all could jeopardise the 'rapport' between the researcher and the participant.

Interviews lasted overall between 30 minutes and 4 hours 30 minutes, with an average of 2 hours 10 minutes. For 12 participants a second (or even a third) interview was planned. This could be on the initiative of the interviewer (to avoid overburdening with lengthy interviews, or when the first interview did not cover every topic), or on the initiative of the participant (when he/she had to leave and wanted to continue his/her story).

As we conducted the interviews from an inductive perspective, we started the interview with an open question, such as: "I don't have fixed questions. You can tell your story how you want it. 
Take your time. Everything you say is valuable. Afterwards I can ask more questions if I want. So, I know you have been in contact with the juvenile justice system as a child. Can you tell me more about that?"

To make sure that different life domains were covered we used a topic list. The analysis of the first sweep of interviews revealed that the narratives did not always provide a sufficient and thorough (indepth) understanding of the long-term impact of being in out-of-home care. To stimulate a more structured and in-depth story we created 'life domain cards' based on the literature and on the previous interviews. These cards were shown to participants during the interviews. We also handed over empty cards so that participants could also suggest new topics. During the interview we tried to get a picture of life domains as described in the literature (e.g. housing, financing, parenting) in the different life periods (before, during and after outof-home care). Throughout the research we added other topics to the list that emerged from the previous interviews, such as dreams, talents and personal development. Very soon it became clear that 'the self' and related topics (e.g. self-image, stigmatisation) were important issues in the life stories and these topics were also added. In most cases, however, participants spontaneously mentioned the topic.

\section{Data analysis}

Because of the inductive perspective we did not select topics in advance for the analysis. Instead, we made use of the interpretative phenomenological analytic method (IPA) (e.g. Reid, Flowers, \& Larkin, 2005). By reading and re-reading the transcripts of the interviews, we tried to understand what the care-leavers were telling us. Understanding meant both "identifying or empathising with as trying to make sense of" (Smith \& Osborn, 2008, p. 54). We searched for recurring key themes in the narratives and afterwards connected our results to the literature. We also made use of narrative analysis, in which we gave attention to the pronouns and verbs care-leavers used to speak about their experiences and changes in the self. We paid attention to the spoken word, but also to other 'embodied' performances of care-leavers, such as the tone of the voice, the gaze, and non-verbal utterances (Dawani, 2016, p. 85).

In order to connect as much as possible with the interview data, we did not use computerised software. We analysed the interviews manually, used coloured labels and made notes in the transcripts.

\section{Findings}

From the stories of care-leavers, it appears that most linked being institutionalised with a changed (or impacted) self-perception. When youngsters narrate about their stay in one or more youth care facilities, they describe how their perception of the self was challenged. The answer to the question "Who am I?" was no longer obvious. Three narratives of the self emerged, which linked the self to having been in care:

1. a collective self or being part of a group and the feeling of obedience and loss of oneself as a consequence;

2. a problematic self or being a problem; and

3. a resilient self or being agentic and resistant in a restrictive context of control.

In the next section, we first describe these three narratives of the self. We then explore the implications of these narratives for the participants' lives (stigmatisation) and how they evolve over time (searching for the lost self).

\section{Three narratives of the self}

\section{A collective self}

"We were placed by the Youth Court, so we were a child of the Court. We are children of the Court." This is what Yvonne, a care-leaver of 66 years, said at the beginning of her interview. She identified herself with "we", referring to the group of children who had been placed by the youth court. During the interview, Yvonne hardly spoke in the 'I' pronoun. And she was certainly not the only one.

The participants (except those who lived in a foster family) had the feeling they became part of a metaphorical collective body (see also De Wilde \& Vanobbergen, 2012, p. 4). Most of the care-leavers lived in a group for a long time. They perceived their institutions as adapted to groups of people and less oriented towards individual needs. According to them, everything happened "together, in group" (Marie, aged 49). However, in a group where everyone is supposed to do and be the same, it is hard to distinguish yourself from others and therefore to preserve a unique sense of self: "Every person has their own character and personality. But I had the feeling that when you are put in an institution, you are all pushed in the same 
direction" (Cindy, aged 21). After all, selfhood is "created by being interactive with other people. It is through interaction and differences you can distinguish yourself from others and this is what makes you 'you'" (Ben, aged 22). Furthermore, participants often had the feeling that they could not be themselves. Therefore care-leavers thought that institutional care-givers taught them indirectly to put on a mask, to become someone else. As Charlotte (aged 25) puts it: "I just lost myself a bit. They didn't concentrate or pay attention to who I was, as a person, as Charlotte."

Some physical characteristics of institutions increase that particular feeling. Everyone had to use the same products (e.g. shampoo, toothpaste) and personal belongings were not allowed or were restricted. Older participants recounted how they had to wear the same uniform and the same haircut. As part of the group, with the same outlook and the same expectations, they had the feeling that their individuality/selfhood was stripped off. The personal self was limited as in a process of mortification: "A series of abasements, degradations, humiliations and profanations of self. His self is systematically, if unintentionally, mortified" (Goffman, 1991, p. 24; see also Irwin \& Owen, 2005). Older participants received a number, which was stitched into their belongings. Younger participants were not physically confronted with losing their name, but they expressed the feeling of being a number or a robot. Living in a group felt as if they became nobody. This feeling was related to the lack of engagement and involvement of institutional care-givers in their life. Cindy expected that they would "give enough attention just as if you would live with your parents. If they don't, you are just a number, like a room number" (Cindy, aged 21).

According to care-leavers, becoming a robot also implied a feeling of suppression and lack of choice and ownership and as a consequence, a lack of dignity (see also Delens-Ravier, 2005; Snacken, 2002). Rita, aged 33, narrated that "you had no choice from the moment you open your eyes in the morning up to the evening. Now you need to do this and now you need to do that." The participants vividly remember the implemented checklists that were based on behaviour modification techniques (reinforcement and punishment) and are a popular system in (Flemish) youth institutions. They were used to evaluate youngsters on several dimensions, such as hygiene, wake up on time, go to school, general attitude, laundry day, etc., which contributed to the feeling of becoming a mechanical object instead of a human being. According to Ben, aged 22, these "checklists are so ridiculous. Then you certainly feel a robot. Every evening you get a check-up. They come to your room with a checklist: order: check; hygiene: check; check, check check, as if I am a car that needs to be checked. And with such action, then I need to feel myself a human being? [These checklists], it's such a pity."

Drawing on the narratives, it seems as if the self becomes almost completely suppressed and led by others. Care-leavers are often left with the feeling that they could not choose their own path in life, and had to be extremely obedient. To illustrate the lack of ownership, we extracted only the verbs and pronouns from a few sentences of the interview of Cindy (aged 21). The use of the pronouns, such as 'we' or 'one', combined with verbs, such as 'must', 'had to' or 'was not allowed', in the next sentences show literally the perceived control and suppression in institutions:

\section{It was compulsory \\ I had to \\ Compulsory \\ One was not allowed to \\ Is not allowed to \\ Is not allowed \\ One is not allowed to laugh \\ Just be quiet}

This perception that they always needed to be obedient to institutional care-givers and were part of the group was accompanied by another perception of the self, a problematic self.

\section{A problematic self}

Some participants perceived their youth care period partly as a breeding ground for personal growth. They link being in care with chances, learning to keep going, to love oneself, to learn their talents, to be a fighter who will never give up, making them strong people. For these care-leavers, being in care did not leave only a negative 'imprint' on the self.

However, most care-leavers in our study looked back mainly with negative feelings. They narrated that when they came into contact with youth care, they had the feeling that they were 'bad children', 
causing trouble. This feeling already started before the juvenile was placed into youth care. Ilona (aged 42), who was physically and sexually abused as a child, asks herself nowadays: "Was I really such a dreadful child? For me this is still a question, but for others, it was just a fact. A lot of people didn't know what happened at home. And my parents always smiled and kept up appearances. It was always me who was disturbing. And I, I was put in an institution, so I was [silence]. That was the way the story circulated. I was portrayed as the problem." Care-leavers who also offended as a juvenile, narrated that the focus was solely on their bad behaviour without looking at the underlying issues causing these problems. Delinquency was, according to them, just a way to compensate for the embodied insecurity and bad feelings about themselves or their environment.

Being sent into care may be experienced as the 'evidence' of being malicious, because they need to be re-educated and removed from society. Charlotte, aged 25, noted that "nobody ever said that it was your fault, but you do think it is. You start to think it through: an institution, what is that? That's a place where you go when something is wrong. You begin to think: it should be me. The one who is placed out of home should be the one who did wrong." The placement in an institution is perceived as the confirmation of their problematic self. As a result, they started to internalise this perception.

From the narratives of the care-leavers, it appears that the problem-focused approach in institutions reaffirms the problematic self. Careleavers had the feeling they were under permanent observation. Johan, aged 53, noted that "everything was written down by institutional care-givers, you were constantly evaluated." Ben, aged 22 , who already mentioned checklists as a way of becoming a robot, also said that "what is on those lists, DEFINES [children in care]. And they start - and to me it also happened after some time - to believe that there should always be a problem in [their] life. Be it just the 'problem' of entering the living room of your institution without slippers! What a shame! Now I'm not a good human anymore! [with sarcasm] But yes, we started to think: this is on the list, I am evaluated on this. What institutional caregivers say I do or do not, that will be the truth."

Also, care-leavers sometimes had the feeling that everything was put under a looking glass; even when there was no problem, a problem was found. For example, one participant spoke about the difficulties she had with expressing sexual feelings when she was in puberty. At the time, she didn't know she was attracted to girls. She said: "I had difficulties with talking about sensitive and intimate feelings such as sexuality. Therefore, institutional care-givers started to think that I was sexually abused by my father. But I never was, fortunately! But due to their search for answers, I started to think myself I probably could be abused. It lasted until some years ago that I finally knew what was happening to me. I just fall in love with girls, nothing more, nothing less" (Rita, aged 33).

The use of case files seems to contribute to this problematisation of behaviour. Everything was reported and they had the feeling they were reduced to files. Three participants had looked into their youth case files as adults and were shocked about the negative picture that was painted about them. They confronted how most of the information was a one-sided story and how their opinion and views on the situation were left out. Positive characteristics of the juvenile concerned were barely mentioned in the case files, resulting in a mainly negative view of the self.

As mentioned by Unrau, Seita and Putney (2008), the devaluation of the self can result in a self-fulfilling prophecy. Kenny, aged 23, mentioned the remarks he got from care-givers in the institution, such as "you are again messing it up" and "if you continue like this, you will end up in prison." These remarks continued despite his effort to improve his behaviour. It finally resulted in "disobeying all the rules, just like they expected me to behave." Participants missed a positive approach in which hope, belief and chances were central. Celine, aged 25, disobeyed a lot of rules when she was staying in an institution. Because of being perceived as 'incorrigible', Celine said, "They give up on me when I was 17 years old. That certainly gave me such a desperate feeling. The feeling of: nobody really believes in me, nobody is interested in who I am, what my struggles are. I started to believe this myself."

In conclusion, the narratives reveal a selfperception of becoming devaluated by others (see also Kools, 1997, 1999). As a result, their selfhood was seriously undermined during and after the period of out-of-home care. According to the careleavers of this study, a problem-directed focus 
contributed to the internalisation of problems in their lives. They start to reduce themselves to a 'child of the institution', which we can define as a constructed care-identity. A more positive approach, directed to empowerment and talents, was exceptional.

Although the majority of the participants associated the period of out-of-home care with suppression and problematisation, and a perceived lack of agency, the narratives show that they did not passively undergo the institutional system. Instead, they also narrated about an agentic or resilient self.

\section{A resilient self}

In an attempt to preserve the self within the institution, different strategies to disobey the rules were used (see also Myers \& Sangster, 2001; Nys, 2016). In this part, we will elaborate on this resistant or resilient self.

For our participants, resistance was often a reaction to the feeling of not being heard $\left(I^{\prime} m\right.$ not silent anymore) and to practices perceived as unjust. On the one hand, this resulted in covert types of resistance. Some examples brought up by our participants are: throwing food into the toilet; asking another youngster to urinate for a drug test (in order to cover drug use); and inventing names such as "Godzilla" for 'mean' institutional caregivers. Another hidden form of resistance was "faking" (Johan, aged 54) or "obeying the rules" (Rita, aged 33), which has a lot of similarities with what Cox (2011) called "doing the program".

The behaviour youngsters displayed suggested that they conformed to the rules. However, they just did what they were supposed to do in order to make themselves comfortable and leave the institution as fast as possible. By listening to our care-leavers, we must understand their behaviour not (just) as conformity, but as resilience within an institutional setting, which does not generate so many other options to speak up. These acts can be understood as a form of agency. As an example, Johan obtained good grades and tried to behave well under the supervision of institutional caregivers. Not because he intrinsically wanted to do it, but he only tried to enhance his chances to end his stay in the institution as quickly as possible. In one way, it resulted in some positive personal changes such as finishing high school with good grades, which Johan initially did not aim to achieve. As Cox describes it: "If you do it long enough, it becomes you" (Cox, 2011, p. 603). However, this obsession resulted also in the loss of himself, because he was often hiding his real feelings, answering institutional care-givers in terms of what they wanted to hear, giving socially desirable answers. Rita also said that she continued this fake behaviour as an adult. She said: "You keep doing those things: I continued pretending and that's something I am not done with yet."

Others also resisted by internalising behaviour, such as suicide attempts or very introverted behaviour. Charlotte, aged 25, said that she "put on a mask as if everything was fine." She suppressed her feelings of intense distress in order to survive the rollercoaster, a metaphor used frequently by care-leavers to describe the hectic period of out-ofhome care. Others tried to preserve their self and resist their collective and problematic self by keeping other children in care at a distance. As an example, Miriam, aged 38, compared it to "locking" herself up in her room, "Figuratively, I mean. Because it was mine... In my room, I could be myself. I did not have to consider other youngsters or institutional care-givers. It was just me, myself and my radio." The radio and music were very important to preserve herself. She identified herself with songs. In her room she was allowed to play her music and also to wear clothes she wanted, just to be herself, without pretending or taking into account others' opinions. There, she felt safe.

As a consequence, this coping mechanism can result in remaining introverted. Rudi, aged 47 , said: "As a child, I was very happy, always smiling, a bit the clown of the family. But when I was placed in the institution, I became very introvert. And I'm still an introvert person. I can even say I have become a misanthrope."

On the other hand adult care-leavers told us about more visible ways to preserve the self. Some used narcotics to keep themselves calm and to cope with situations before and during their stay in the institution. Others started to run away. According to Fernando, aged 25, "Running away does always have a reason. Nobody runs away because of, well, you run away because there is something. You do not feel well, you are not happy, something bothers you." As stated by llona, aged 42, running away became a way of "escaping the confrontation with the past. The moments I was in the institution, they expected me to process the traumas I have experienced. But I did not want to. Not yet." It was 
only as an adult that she felt the necessity to cope with the past and move on. Furthermore, it was hard to tolerate some decisions, which were taken over their heads. This resulted sometimes in aggression towards material, other people or themselves as a way to canalise frustration and anger. As noticed by Wilson (2003, p. 421), it was often "reserved for moments of crisis, ... to employ when 'keeping quiet' failed to deliver the life that they wanted, or when a line was crossed". Speaking up loudly, using verbal aggression, was a way to cope with their feelings of powerlessness. Being articulate became a weapon of resistance.

\section{How these narratives impact on life and change over time}

"If you really are searching for those aspects in my life in which my trajectory in care is noticeable, then I think the answer is in my whole body, it's the way I am. It's in everything I do and do not." (Rita, aged 33)

It is important to explore internal self-perception processes because changes on the outside (the social transition) may only provide a partial view of adult outcomes. How care-leavers feel on the inside is illustrated by some participants' stories. For example, Vera, aged 32, narrated: "They kept saying to me: you've made it in life, I see. I SEE. And then I thought: maybe I feel terrible, but I look decent, I have a house, I'm married, I have children and a washing machine [Vera smiles]." According to Vera these markers of life, including the washing machine, were an indication of stability. In other words, Vera looked fine on the outside, but she did not feel fine as she was still struggling with her past.

In what follows we discuss how, according to the care-leavers, these narratives of the self impacted their lives, and how they evolved with age. The interviews reveal that younger care-leavers are still very moved by their care identity. Mostly, they still feel different from other people and construct their self-conceptions around having been in care. Older care-leavers were more confident and could also see what they did realise in life despite, or thanks to, their life in youth care. They start to renounce the previously constructed 'care identity', shifting their narratives of self in a positive way. At first, they encounter specific consequences in life due to their constructed perception of the self while in care: feelings of stigmatisation. Afterwards, turning points and related mental processes improved their search for new or adapted narratives of the self not only affected by their experiences in care.

\section{Stigmatisation}

In the participants' stories a feeling of the loss of 'normalisation' emerges. Care-leavers felt as if they were 'odd' persons with weird habits. For example, a care-giver of the institution and not the parents came to school for parents' evening. Some told us about how friends started to ignore them "as if you have become a 'freak'. Or they become very nosy and start asking questions such as: 'Why are you living in an institution?' and afterwards you see them whispering and joking with each other" (Rita, aged 33). Also, youngsters in care do not always have the choice to choose a hobby outside the institution. They always have to ask permission to go to a sleepover or a birthday party of a friend, and spontaneous events aren't always possible. As a consequence, they had the feeling they were different from their peers (see e.g. Michell \& Scalzi, 2016). Being confronted with the differences confirmed their feeling of being abnormal and of being an 'outsider'.

The loss of feeling 'normal' and the selfperception of being 'odd' may be mediated by stigma. Stigma impacts how people see themselves and how they think they will be perceived by others (Breen, 2014). Indeed, several participants expressed the feeling of being stigmatised and of being seen differently than before. According to some, society has always had a negative perception of juveniles in out-of-home care, as one participant narrated: "Something that has hurt me very often and made me angry, were the prejudices when I told people I had been in a youth institution for a while. The answer was often: 'Oh, did you commit a crime?' or 'You must have been a rebellious child'. ... Although we were just kids in a difficult situation, with parents who had no clue how to solve their problems with alcohol, drugs, prostitution, disabilities, and etc. ... And when I tell people that I work with youngsters in residential youth care [now], I get similar responses: 'Wow, you work with difficult, rebellious, delinquent youth' or even worse 'with pigs' or 'with weeds'" (Mira, aged 38). So, the image is predominantly fuelled by the so-called dangerous or criminal characteristics of minors in youth care.

During the period in youth care, this stigmatisation is mainly present at school or in leisure activities. As an adult, care-leavers are 
confronted with the effect of these stigmas when they start to look for a job, specifically when they search for a job as an institutional care-giver. The same is encountered when searching for housing. Nevertheless, based on our participants' narratives it seems as if that stigmatising effect may diminish with age. According to Marie, aged 49, it is less conspicuous if your family is no longer part of your social network. After all, a lot of participants have lost their parents by middle age. Furthermore, Vera, aged 33, pointed out, "When you are older, you are less questioned about your childhood. The people you know are aware of your history, and new people don't ask questions about the past."

\section{Searching for the lost self}

"I am searching for the new me. Such as: who is Charlotte, apart from the institutions, apart from what happened to me. Who is she? And that's already a burden, a heavy cross to bear." (Charlotte, aged 25)

Listening to the stories of adult care-leavers, we notice how boundaries of the self, mentally and physically, were not always respected. Therefore, the self was not only marked by the institution, but also by traumas of experienced violence, maltreatment, sexual abuse, etc. About half of our participants reported psychological problems in adulthood (two men, 16 women). For some of them, these problems occurred only during a short period of time, as narrated by Cedric, aged 34: "When I left the institution, my mental state was not good. I was depressed. I didn't get up, I stayed at home, I was just staring to the walls and ceiling. I was excluded from friends. Due to my stay in a closed institution, my self-esteem had totally vanished." For a larger group of participants, longterm and intensive psychological support was needed to overcome traumas from the past.

Six participants recounted being in therapy in the past (six women), and six more reported that they still are in therapy today (one man, five women). For another six participants, psychological problems even led to a stay in a psychiatric institution at some point in adulthood (one man, five women). Remarkably, far more women than men report that they were/are in therapy. It is, however, not clear how this may be understood. Women may have more traumatic pasts and/or may react differently to traumatic events (see e.g. Dixon, Howie, \& Starling, 2004), having a greater need for psychological help. Men may also underreport traumatic events (Pieters, Italiano, Offermans, \& Hellemans, 2010). Another remarkable finding is that for a lot of care-leavers, the start of processing traumatic events only starts later in adulthood. Studies scrutinising long-term outcomes of adult care-leavers have found that life conditions often improve with age (see e.g. Duncalf, 2010; Frechon \& Dumaret, 2008). In our study we found that it is often at that moment, when life becomes more stable, people feel ready to look back and deal with their past: "When I was in care, institutional care-givers were there to support me, but I could not talk about my 'backpack'. This was only possible when I was an adult. For a long time I was in the 'never look back, just keep moving forward' drive. It was only some years ago I was able to gradually open this "backpack'" (Vera, aged 33). This means that changes in the social situation, marking social transitions, engender changes in selfperception. Sometimes the skills taught by and tools introduced by institutional care-givers or other professionals are only used years after leaving care, when the care-leaver is ready: "After some years I realised what I was doing. You become more mature and at that very moment you start to use the tools they teach you in those days [in the institution]" (Glenn, aged 33).

For others, the processing of their problems comes quite unexpectedly. Some participants experienced a delayed processing instigated by sudden physical or psychological problems, such as hyperventilation and panic attacks at a later age. Based on our findings, psychological difficulties started to manifest/ disclose themselves between the ages of 20 and 40 . Mireille, aged 48 , shared that "along the years, something starts to develop inside you. You automatically develop a pattern, but you are not aware of that pattern. Until you grow older. Finally, it hits you, like a boomerang." Sometimes, it was only by consulting a professional that the link with their past was discovered, initiating its processing. For example Roos, aged 41, encountered problems of hyperventilation and muscular pains at age 37, leading her doctor to conclude that her physical problems were rooted in her traumatic past. Roos started seeing a therapist to process her past.

The narratives reveal that the process of a changed self-perception may be triggered by specific life events, such as having a job; a good neighbour or boss who takes care of them; a 
disease such as cancer; or death, overdose or detention of a good friend. In that sense, several participants consider these events as turning points. Turning points are seen as "perceptual roadmarks along the life course. They represent individuals' subjective assessments of continuities and discontinuities over their lives, especially the impact of earlier life events on subsequent ones. In some cases, turning points are perceived as critical changes, in other cases as new beginnings" (Hareven \& Masaoka, 1988, p. 272). Turning points are often seen as single events triggering a change, rather than altered circumstances over a longer period in time (Enz \& Talarico, 2016).

In this contribution, we focus on two turning points that were described by almost every careleaver we interviewed.

An often-voiced event, perceived as a turning point, is starting to work as an institutional caregiver in youth care. Scrutinising adult job outcomes, it appears that 23 of our 38 participants are currently working or pursuing training. The remaining 15 persons do not work anymore as they are retired $(n=3)$, declared unfit for work due to physical and/or psychological problems $(n=5)$, unemployed $(n=3)$ or in prison $(n=1)$. Another three (men) are currently involved in the illegal drug trade. Three women used to work in illegal practices (prostitution/drugs) but had quit at the time of the interview.

Of the 23 people working or following an education, eight work in construction or factories. Remarkably, the other 15 are working in the social sector or are pursuing training in this field. Many participants said they decided to pursue a social education in order to work with youngsters in care. It appears that the care-leavers in our study often started or continued their education later in life, once it became more stable. Working as an 'experience expert' seems important in prompting inner change. With this job, care-leavers express their desire to serve as a role model for juveniles in care, showing that care-leavers can make it in life. Considering themselves a role model also impacts their self concepts, as they "internalise a new set of conduct norms" (Keller, 1993, p. 77). Their peers serve as a mirror, helping them to gain more insight into their own problems and functioning, ultimately changing their own behaviour (Parkin \& McKeganey, 2000) and invoking self-rehabilitation (Keller, 1993, p. 79). In that sense, the difficult circumstances they encountered can result in "a springboard for progression" (Pinkerton \& Rooney, 2014, p. 8).

The feeling of being able to make a change, to mean something for others, not only gives a new meaning to their lives, but it also creates space for a new (conventional) role, shedding a positive light on the self. Through these roles their own past can be 'repaired'. It is as if 'redemption' comes by helping others, especially others growing up in similar circumstances as their own: "If you can pass on some skills to people who are at the start of their adult life, if you can give them a boost to help them to have a better future [silence], to me, that is very important, that you can protect them for what I went through when I was of the same age. If they will learn from my mistakes, I am happy." (Geert, aged 43)

A second important turning point expressed by our participants is parenthood. In our sample, 14 women are mothers, and eight men are fathers. Mainly female participants described becoming a parent as a positive turning point. Women also talk more about their children in the interviews.

However, for women, giving birth may at first evoke negative feelings as it confronts them with their own traumatic past. For example Els, aged 40, had a difficult moment when she was pregnant with her first child. She was aware of her precarious life situation and was afraid that having a baby was not the best scenario: "How do you raise a child when you never saw your parents doing this? I struggled with it for nine months. I didn't want to be pregnant, in fact." Only in a second phase the pregnancy turned out to be a positive, life-changing event: "The day that I gave birth to my daughter and when they laid her on my chest, the first thing I said was: this is my daughter and nobody will ever touch her." Els is a victim of sexual abuse. She promised her daughter she would protect her from similar victimisation. Becoming a parent meant something to live for: a new and positive role, impacting positively on self-esteem.

On the one hand, women talk about how having their first child made a change in their lives. It marked a fresh start, a new beginning and a way to give another meaning to their lives. For some, parenthood appeared to be the only source of meaning in life. On the other hand, becoming a parent is a way to heal wounds or to put a hold on intergenerational transmission (Buchbinder, 2004; 
Pryce \& Samuels, 2010; Van Audenhove \& Vander Laenen, 2011). With parenthood, care-leavers may want to 'repair the past' (see also Berckmans, 2015; Buchbinder, 2004). By raising their own children differently than their parents, they hope to repair, correct or rectify the past. The literature refers to this as "reparation", "corrective experience" or "righting the wrongs" (Hardesty \& Black, 1999; Shamai \& Kochal, 2008). Trying to give their children a better childhood than their own, parenthood may be considered as a "motive for change" (Shamai \& Kochal, 2008, p. 332). Anna, aged 58, for example, recounts: "When I gave birth to my son, I didn't want to be a prostitute anymore or carry drugs from place A to place B. I was so afraid I would lose my son if I would continue to do these things. And my own past in institutions [silence], I just didn't want to lose him [silence]. I said: no, I want a normal life for my son."

The dynamics invoked by parenthood show remarkable resemblance with desistance studies. Desistance research has shown that parenthood may impact positively on desistance and reintegration (see e.g. Baumeister, 1991; Laub \& Sampson, 2001) and that parenthood is especially crucial in the lives of female (ex-)offenders. (Re)claiming motherhood as a conventional identity and the feeling of being useful and valuable may facilitate desistance and reintegration (Ferraro \& Moe, 2003; Giordano, Cernkovich, \& Rudolph, 2002; Rodermond, Kruttschnitt, Slotboom, \& Bijleveld, 2016; Sharpe, 2015).

Additionally we noticed that giving birth may also instigate reflection about the past, and more specifically about the question: "Who am I?" Questions about the past are sometimes pushed away or ignored for years. However, giving birth and watching a child grow up confronts care-leavers with questions about their own childhood (how did I look, how old was I when I started walking, etc.). It's at that very moment that several care-leavers take steps to look into their youth care file. Being informed of their family history helps them to figure out their lost self, as mentioned by Eva, aged 43: "These are (little detail) parts of my identity, which I don't know and which are, according to me, very important" (see also Kools, 1997; Molley, 2002). Some questions are important for their children (e.g. genetic information) and some feel the need to receive answers to other questions. For example, Mireille, aged 48, started asking herself: "How is it possible that a mother [her mother] lets her children be taken away and does not fight for them?" A lot of care-leavers in our sample, especially the older ones, have no pictures or other tangible memories left from their time in care: "Other people have a lot of pictures of themselves as a child. I don't have it. Sometimes, I miss this. I miss information, about how I was as a child or as an adolescent, such kind of things" (Fien, aged 33). This adds to the feeling of being just a number. Younger participants more often have photo books with memories, and that seems to contribute to the construction of the self.

Another resemblance with desistance studies is the emergence of a 'generative script' (see e.g. Maruna, 1997). While they aged out of care, the majority of care-leavers developed a storyline in which the negative events and demons of the past fade away and become re-scripted by more positive images (McAdams, 2013; Silva, 2012). As Silva (2012, p. 514) notes, they "grounded their adult identities in their personal quests to transform their wounded selves". By reconstructing and retelling this narrative of self, they confirm the change within their lives. Their behaviour and actions can be seen as a 'window' to change.

\section{Discussion and conclusion}

In order to explore how care-leavers experienced growing up in out-of-home youth care, and how they perceived the impact of this on their later lives, we conducted life history interviews with 38 adult care-leavers in Flanders (21-66 years). Since this small number of participants was mainly recruited through advocacy groups $(n=20)$, we should bear in mind that our recruitment strategy might have affected our results. Also, we are aware that we may have missed groups of care-leavers who are harder to reach. It appears that both those who are the most advantageously situated and have succeeded in disassociating themselves from their institutional past, and those who are in the least advantageous situations (e.g. those who ended up living on the streets) are harder to reach and underrepresented in research (Issenhuth, Vivier \& Frechon, 2010, p. 188).

Nevertheless, our research has delivered important insights about the subjective impact of being in care on the subsequent life course.

First, the narratives clearly show an initial decrease or even loss of selfhood. A stay in one or more care facilities seems to have contributed to a 
feeling of being just a number within the group of institutionalised youngsters with a focus on problematic behaviour. In the literature, researchers referred to this identification as a "care-identity" (Dima \& Skehill, 2011, p. 2537). Since this care-identity is described in a similar way across the age groups, important historical pedagogical changes in youth care practices have apparently not yet led to notable changes in this anonymous and problematic care-identity. Certain mechanisms seem to be intrinsic to the system of out-of-home care and deprivation of liberty. While participants' stories are situated in different places and years, many stories were quite alike. One important difference, however, is that older careleavers literally were a number (e.g. their number was stitched in their belongings). The narratives show that a negative discourse about care-leavers still prevails, leading to stereotypical views of the self as 'deficient': as people who cause trouble and are nobodies (see also Michell \& Scalzi, 2016). While a loss of agency is also indicated, several care-leavers did develop resistance strategies in an attempt to preserve the personal self and reject the collective and problematic self of the care identity.

Our research shows that being in out-of-home care clearly invokes feelings of stigmatisation. For most care-leavers, stigmatisation and identification with the group of institutionalised youth leaves a negative imprint on the self. Although the label of 'care-leaver' seems to be a more neutral label than, for example, 'ex-offender', care-leavers stress that society often thinks of people in care as juvenile offenders or bad children. Drawing on the narratives, we find evidence that the care identity and its negative imprint often diminish over time. As care-leavers age, new and more conventional self-presentations are developed. The care-leaver is not just a care-leaver anymore, but also a mother, a father, a youth care worker and so on. Hence, the changing perspectives on themselves may be engendered by processes typical of the life course of all people, and not just of care-leavers. These triggers, however, produce a specific motivation, in particular acting as a change-maker in order to help the next generation and at the same time trying to defeat the demons of their own past (see also Buchbinder, 2004; Silva, 2012).

Second, our research has clearly demonstrated the importance of exploring subjective processes when investigating the impact of being in care on the life course. In order to initiate or complete the quest for a lost (or new) self as an adult, the processing of traumatic events seems to be crucial. Also, it clearly appears that parenthood and a job in the social care sector are perceived as important turning points for a changed perception of self. Remarkably, this transformation is often prompted some years after exit from care, stressing the importance of a longitudinal perspective. More research is needed to understand how these turning points influence self-reconstruction. Refining our understanding of the change of selfperception throughout the period of being in care and beyond is important to come to a more complete picture of adult outcomes of care-leavers. Most studies on adult care-leavers focus on a quantitative assessment of that which is 'objectifiable', such as criminal justice contacts, housing situation, health care involvement or (un)employment. Based on these factors, adult social inclusion/integration is assessed. However, as we argued, these factors mainly provide an 'outside look' at the adult outcome of being in care. Less attention is paid to the self of care-leavers and its transitions through time. When assessing adult outcomes, we need to include the 'inside' view. Concepts of '(un)successful transitions' or 'success stories' should also be shaped by how people are doing according to themselves (Nuytiens \& Geluyckens, 2015). Hence, if we want to acquire a qualitative insight into and understanding of how youth protection interventions impact the lives of youngsters and their families, we need research that voices precisely their experiences (de Graaf, Christiaens, \& Dumortier, 2016).

In doing so, a qualitative perspective seems recommended to fully grasp the 'impact' of being in care on lives. This kind of research, like ours, challenges the negative picture painted in the literature on adult outcomes of care-leavers. It shows that the absence of meeting the traditional markers of success in adulthood (e.g. graduating, having a good job) contributes to a reflexive restructuring of the self and the construction of an alternative narrative (see also Giddens, 1991; Silva, 2012). From our data, a more positive picture emerges of self-change and 'redemption' in the long run.

Third, the narratives of the self, and the ways these narratives are perceived by care-leavers over time, show a strong resemblance with processes 
described in contemporary desistance literature. This again shows how youth protection practices are still judicial practices in which social assistance and punishment, and their unintentional consequences, are intertwined. For example, the need to develop an alternative, conventional identity is described as key to the desistance process (see e.g. Maruna, 2001). In that sense, the process of moving away from the care identity can be seen as a way of moral rehabilitation as McNeill (2012) mentioned in his four forms of offender rehabilitation. In the process of rehabilitation, offenders enlarge their former narrow self (they identified themselves with the offender narrative) to a multiple self, in which other conventional selves (e.g. parent, social worker) are present. This helps, as Maruna puts it, to "develop a coherent, pro-social identity for themselves" (Maruna, 2001, p. 7). Drawing on this literature, we may expect that the care identity will not disappear completely, but that it will co-exist with new and conventional selfnarratives, pushing the care identity more to the background.

Also in line with desistance studies, our results show that some social events were considered as important turning points instigating internal changes, such as shifting self-perception and selfworth. The narratives show that while both the processing of traumatic events and the occurrence of life events (e.g. parenthood, a job in youth care) are said to be catalysts (or even basic conditions) in processes of internal change, participants also have to feel 'ready' to make a change. This refers to the importance, according to desistance studies, of life events as turning points combined with intrinsic motivation (Laub \& Sampson, 2003; Maruna, 2001). But then again, both our study and the desistance literature questions the qualitative and long-term 'impact' of youth justice interventions on the involved youngsters as they become adults.

Finally, our study shows that care-leavers' selfreconstruction is a long-term process. This has implications for policy and practice as well as for future research.

At first, caregivers (institutional care-givers, foster parents, etc.) need to encourage a positive self-perception. Instead of only managing problematic behaviour, professional care needs to be hopeful. Caregivers should recognise and stimulate the talents, strengths and competencies of young people and their capacity for resilience in order to minimise the construction of a negative self-perception. When a youth's self-esteem is so vulnerable, due to several negative circumstances, he/she needs someone who cherishes hope and faith that everything will be fine. This can result in new hope for and a new self-perception of the youngster or care-leaver.

Moreover, given the stigmatisation often confronting care-leavers, it is necessary to raise awareness of the impact of a history of being in care on the lives of care-leavers. At the same time, it is important to stress that these youngsters (adults) are not solely defined by this experience (see also Wilson \& Golding, 2016).

Secondly, several studies have revealed that aftercare in emerging adulthood is often lacking or limited (see e.g. Mendes, Pinkerton, \& Munro, 2014; Nuytiens \& Geluyckens, 2015; van der Geest et al., 2013). Acknowledgement of the changed selfperception, induced by care, and its long-term consequences, may inspire aftercare policies to provide care-leavers with the support and care facilities they need to maximise their wellbeing. However, today, psychological aftercare services for care-leavers are very uncommon and/or not easily accessible (see e.g. Höjer \& Sjöblom, 2014).

Thirdly, a long-term perspective should be included in future research. Scientific literature mentions that the life phase of emerging adulthood (18-25 years) is characterised by identity exploration and a focus on the self (Arnett, 2004). Most studies of adult outcomes of care-leavers focus on youngsters who find themselves in the phase of emerging adulthood (see however Duncalf, 2010; van der Geest et al., 2013). Although this research was an exploratory study, we can conclude that it is essential to look beyond emerging adulthood in future research on adult care-leavers to understand the unintentional consequences of care. Our study shows that, for many, questions about "Who am I?" and the shaping of identity and the self continue well beyond the age of 25 . While the exact course of the process of this change in self-perception and its timing may be different for every care-leaver, we found that moving away from the care identity and embracing other conventional identities takes more than a couple of years. A long-term perspective is crucial because the achievement of a more positive self-perception often occurs at a later age. This means that long-term perspectives and 
interventions may result in different and more positive results.

The narratives demonstrate the importance of advocacy groups and of becoming an 'experience expert' social worker committed to reforming youth care practices and serving as a role model for the next generation. This 'role-model quest', and accompanying self-redemption, deserve further exploration.

\section{Acknowledgements}

The authors are grateful to the Network Project Interuniversity Attraction Pole (IAP) P7/22 "Justice \& Populations: The Belgian Experience in International Perspective, 1795-2015" for funding the PhD research of llse Luyten.

\section{References}

Abrams, L. (2010). Oral history theory. Abingdon: Routledge.

Apfelbaum, E. (2010). Collective memory. In S. Radstone \& B. Schwarz (Eds.), Memory: histories, theories, debates (pp. 77-92). New York: Fordham University Press.

Arnett, J. J. (2004). Emerging adulthood: The winding road from the late teens through the twenties. Oxford: Oxford University Press.

Arnett, J. J. (2007). Afterword: Aging out of care- Toward realizing the possibilities of emerging adulthood. New Directions For Youth Development, 113, 151-161. https://doi.org/10.1002/yd.207

Barth, R. P. (1990). On their own: the experiences of youth after foster care. Child \& Adolescent Social Work, 7(5), 419-440. https://doi.org/10.1007/BF00756380

Baumeister, R. F. (1991). Meanings of life. New York: Guilford Press.

Baumeister, R. F. (1998). The Self. In D. T. Gilbert, S. T. Fiske, \& G. Lindzey (Eds.), The handbook of social psychology. (4th ed., vol. 1, pp. 680-740) New York: McGraw-Hill.

Berckmans, I. (2015). Sharing stories, reflecting and creating ideas about leaving the streets: encounters with young persons in street situations, their family members and street educators through participatory action research projects in El Alto, Bolivia. Unpublished dissertation, Vrije Universiteit Brussel, Brussels.

Bloom, B., Owen, B., Rosenbaum, J., \& Deschenes, E. P. (2003). Focusing on girls and young women. Women \& Criminal Justice, 14(2-3), 117-136. https://doi.org/10.1300/J012v14n02 06

Breen, C. D. (2014). Stigma. In J. M. Miller (Ed.), The encyclopedia of theoretical criminology (pp. 835-839). Chichester: Wiley. https://doi.org/10.1002/9781118517390.wbetc095

Bruner, J. (2004). Life as narrative. Social Research, 71(3), 691-710.

Buchbinder, E. (2004). Motherhood of battered women: The struggle for repairing the past. Clinical Social Work Journal, 32(3), 307-326. https://doi.org/10.1023/B:CSOW.0000035110.10602.ec

Callero, P. L. (2003). The sociology of the self. Annual Review of Sociology, 29, 115-133. https://doi.org/10.1146/annurev.soc.29.010202.100057

Carr, N. \& McAlister, S. (2016). The Double-Bind: Looked after children, care-leavers and criminal justice. In P. Mendes \& P. Snow (Eds.), Young people transitioning from out-of-home care (pp. 3-21). London: Palgrave Macmillan. https://doi.org/10.1057/978-1-137-55639-4 1

Courtney, M. E., Piliavin, I., Grogan-Kaylor, A., \& Nesmith, A. (2001). Foster youth transitions to adulthood: A longitudinal view of youth leaving care. Child Welfare, 80(6), 685-717.

Cox, A. (2011). Doing the programme or doing me? The pains of youth imprisonment, Punishment \& Society, 13(5), 592-610. https://doi.org/10.1177/1462474511422173

Dawani, S. (2016). Self-performances. Palestinian adolescents and the power of collaborative and dialogical spaces. Unpublished dissertation, Vrije Universiteit Brussel, Brussels. 
de Graaf, E., Christiaens, J. \& Dumortier, E. (2016). Children behind Belgian bars: Rights and resistance against the pains of imprisonment. In T. Liefaard \& J. Sloth-Nielsen (Eds.), The United Nations Convention on the Rights of the Child: Taking stock after 25 years and looking ahead (pp. 611-633). Leiden: Brill| Nijhoff.

De Wilde, L., \& Vanobbergen, B. (2012). Mag ik dit vertellen? Stemmen uit de Gentse weeshuizen (19451984). Leuven: Acco.

Delens-Ravier, I. (2005). Enfermement: le vécu des jeunes. In J. Christiaens, D. De Fraene, \& I. Delens-Ravier (Eds.), Protection de la jeunesse. Formes et réformes (pp. 153-163). Brussels: Bruylant.

Dima, G. \& Skehill, C. (2011). Making sense of leaving care: The contribution of Bridges model of transition to understanding the psycho-social process. Children and Youth Services Review, 33, 2532-2539. https://doi.org/10.1016/i.childyouth.2011.08.016

Dixon, A., Howie, P. \& Starling, J. (2004). Psychopathology in female juvenile offenders. Journal of Child Psychology and Psychiatry, 45(6), 1150-1158. https://doi.org/10.1111/j.1469-7610.2004.00307.x

Dumaret, A.-C., Donati, P., \& Crost, M. (2011). After a long-term placement: Investigating educational achievement, behaviour, and transition to independent living. Children \& Society, 25(3), 215-227. offenders. Journal of Child Psychology and Psychiatry, 45(6), 1150-1158.

Dumortier, E., Christiaens, J. \& Nuytiens, A. (2017). Belgium. In S. H. Decker \& N. Marteache (Eds.), International Handbook on Juvenile Justice (2nd ed., pp. 239-265). New York: Springer. https://doi.org/10.1007/978-3-319-45090-2 12

Duncalf, Z. (2010). Listen up!: adult care-leavers speak out: the views of 310 care leavers aged 17-78. Manchester: Care Leavers' Association.

Enz, K. F., \& Talarico, J. M. (2016). Forks in the road: Memories of turning points and transitions Applied Cognitive Psychology, 30(2), 188-195. https://doi.org/10.1002/acp.3176

Felitti, V. J. (2002). Belastungen in der Kindheit und Gesundheit im Erwachsenenalter: die Verwandlung von Gold in Blei [The relationship of adverse childhood experiences to adult health: Turning gold into lead]. Zeitschrift für Psychosomatische Medizin und Psychotherapie, 48(4), 359-369. https://doi.org/10.13109/zptm.2002.48.4.359

Ferraro, K. J., \& Moe, A. M. (2003). Mothering, crime and incarceration. The Journal of Contemporary Ethnography, 32(1), 9-40. https://doi.org/10.1177/0891241602238937

Flick, U. (2004). Constructivism. In U. Flick, E. von Kardoff, \& I. Steinke (Eds.), A Companion to Qualitative Research (pp. 88-94). London: Sage.

Frechon, I. \& Dumaret, A.-C. (2008). Bilan critique de 50 ans d'études sur le devenir adulte des enfants placés. Neuropsychiatrie de l'enfance et de l'adolescence, 56(3), 135-147. https://doi.org/10.1016/j.neurenf.2008.01.015

Gatti, U., Tremblay, R. E., \& Vitaro, F. (2009). latrogenic effect of juvenile justice. Journal of Child Psychology and Psychiatry, 50(8), 991-998.Giddens, Anthony (1991). Modernity and Self-Identity. Self and Society in the Late Modern Age. Cambridge: Polity Press. https://doi.org/10.1111/i.1469$\underline{7610.2008 .02057 . x}$

Giddens, A. (1991). Modernity and Self-Identity. Self and Society in the Late Modern Age. Stanford: Stanford University Press

Giordano, P. C., Cernkovich, S. A., \& Rudolph, J. L. (2002). Gender, crime, and desistance: Toward a theory of cognitive transformation. American Journal of Sociology, 107(4), 990-1064. https://doi.org/10.1086/343191

Goddard, J., Murray, S., \& Duncalf, Z. (2013). Access to child-care records: A comparative analysis of UK and Australian policy and practice. British Journal of Social Work, 43(4), 759-774. https://doi.org/10.1093/bjsw/bcs004

Goffman, E. (1991). Asylums. Essays on the social situation of mental patients and other inmates. London: Penguin Books.

Hardesty, M., \& Black, T. (1999). Mothering through addiction: a survival strategy among Puerto Rican addicts. Qualitative Health Research, 9(5), 602-619. https://doi.org/10.1177/104973299129122117 
Hareven, T. K., \& Masaoka, K. (1998). Turning points and transitions: perceptions of the life course. Journal of Family History, 13(3), 271-289. https://doi.org/10.1177/036319908801300301

Höjer, I. \& Sjöblom, Y. (2014). Voices of 65 young people leaving care in Sweden: "There is so much I need to know!" Australian Social Work, 67(1), 71-87. https://doi.org/10.1080/0312407X.2013.863957

Irwin, J., \& Owen, B. (2005). Harm and the contemporary prison. In A. Liebling \& S. Maruna (Eds.), The effects of imprisonment (pp. 94-117). Cullompton: Willan Publishing.

Issenhuth, P., Vivier, G. \& Frechon, I. (2010). Concilier les droits de chacun: une éthique en dynamique. Enquête auprès de mineurs « protégés ». In S. Laurens \& F. Neyrat (Eds.), Enquêter: de quel droit ? (pp.187-209). Bellecombe-en-Bauges: Editions du Croquant.

Keller, R. L. (1993). Some unanticipated positive effects of a juvenile awareness program on adult inmate counselors. International Journal of Offender Therapy and Comparative Criminology, 37(1), 75-83. https://doi.org/10.1177/0306624X9303700107

Kools, S. M. (1997). Adolescent identity development in foster care. Family Relations, 46(3), 263. https://doi.org/10.2307/585124

Kools, S. M. (1999). Self-protection in adolescents in foster care. Journal of Child and Adolescent Psychiatric Nursing, 12(4), 139-152.Larkin, M., Watts, S., \& Clifton, E. (2006). Giving voice and making sense in interpretative phenomenological analysis. Qualitative Research in Psychology, 3(2), 102-120. https://doi.org/10.1111/j.1744-6171.1999.tb00063.x

Laub, J. H., \& Sampson, R. J. (2001). Understanding desistance from crime. Crime \& Justice, 28, 1-69. https://doi.org/10.1086/652208

Laub, J. H. \& Sampson, R. J. (2003). Shared beginnings, divergent lives: delinquent boys to age 70. Cambridge, MA: Harvard University Press.

Lincoln, Y. S., \& Guba, E. G. (2003). Ethics: the failure of positivist science. In Y. S. Lincoln \& N. K. Denzin (Eds.), Turning points in qualitative research. Tying knots in a handkerchief (pp. 219-237). Walnut Creek: Altamira Press.

Maeve, M. K. (2000). Speaking unavoidable truths: understanding early childhood sexual and physical violence among women in prison. Issues in Mental Health Nursing, 21(5), 473-498. https://doi.org/10.1080/01612840050044249

Maruna, S. (2001). Making good: how ex-offenders reform and reclaim their lives. Washington, DC: American Psychological Association Books. https://doi.org/10.1037/10430-000

Maruna, S. (1997). Going straight. Desistance from crime and life narratives of reform. In A. Lieblich \& R. Josselson (Eds.), The narrative study of lives - Volume 5 (pp. 59-93). London: Sage Publications.

McAdams, D. P. (2013). The positive psychology of adult generativity: Caring for the next generation and constructing a redemptive life. In J. D. Sinnott (Ed.), Positive psychology (pp. 191-205). New York, NY: Springer New York. https://doi.org/10.1007/978-1-4614-7282-7 13

McCord, J. (1978). A thirty-year follow-up of treatment effects. American Psychologist, 33(3), 284-289. https://doi.org/10.1037/0003-066X.33.3.284

McCord, J. (2002). Counterproductive juvenile justice. The Australian and New Zealand Journal of Criminology, 35(2), 230-237. https://doi.org/10.1375/acri.35.2.230

McClellan, D. S., Farabee, D. \& Crouch, B. M. (1997). Early victimization, drug use, and criminality. A comparison of male and female prisoners. Criminal Justice and Behavior, 24(4), 455-476. https://doi.org/10.1177/0093854897024004004

McNeill, F. (2012). Four forms of "offender" rehabilitation: Towards an interdisciplinary perspective. Legal and Criminological Psychology, 17(1), 18-36. https://doi.org/10.1111/j.2044-8333.2011.02039.x

Mendes, P., Pinkerton, J. and Munro, E. R. (2014). Young people transitioning from out-of-home care: An issue of social justice. Australian Social Work. 67(1), 1-4. https://doi.org/10.1080/0312407X.2014.867471

Mendes, P. \& Snow, P. (Eds.) (2016) Young people transitioning from out-of-home care: International research, policy and practice. London: Palgrave Macmillan. https://doi.org/10.1057/978-1-137$\underline{55639-4}$ 
Michell, D., \& Scalzi, C. (2016). I want to be someone, I want to make a difference: Young care leavers preparing for the future in South Australia. In P. Mendes \& P. Snow (Eds.), Young people transitioning from out-of-home care: International research, policy and practice (pp. 115-133). London: Palgrave Macmillan. https://doi.org/10.1057/978-1-137-55639-4 6

Miyahara, M. (2010). Researching identity and language learning: Taking a narrative approach. Language Research Bulletin, 25, 1-15.

Molley, V. (2002). Identity, past and present, in a historical child-care setting. Psychodynamic Practice, 8 , 163-178. https://doi.org/10.1080/13533330210154538

Murray, S. (2015). Supporting adult care-leavers: International good practice. Bristol: Policy Press. https://doi.org/10.2307/j.ctt1t89567

Myers, T., \& Sangster, J. (2001). Retorts, runaways and riots: Patterns of resistance in Canadian reform schools for girls, 1930-60. Journal of Social History, 34(3), 669-697. https://doi.org/10.1353/ish.2001.0025

Nuytiens, A. \& Geluyckens, T. (2015). Researching transitions of youngsters formerly involved in the youth protection system. In J. Christiaens (Ed.), It's for your own good. Researching youth justice practices (pp. 373-389). Brussels: VUBPress.

Nys, L. (2016). Emotie, gender en macht. Historica, 1, 17-22.

Parkin, S., \& McKeganey, N. (2000). The rise and rise of peer education approaches. Drugs: Education, Prevention and Policy, 7(3), 293-310. https://doi.org/10.1080/09687630050109961

Pasupathi, M. (2001). The social construction of the personal past and its implications for adult development. Psychological Bulletin, 127(5), 651-672. https://doi.org/10.1037/0033-2909.127.5.651

Pieters, J., Italiano, P., Offermans, A.-M. \& Hellemans, S. (2010). Ervaringen van vrouwen en mannen met psychologisch, fysiek en seksueel geweld. (Emotional, physical and sexual abuse - the experiences of women and men.) Brussels: Instituut voor de gelijkheid van vrouwen en mannen.

Pinkerton, J. \& Rooney, C. (2014). Care leavers' experiences of transition and turning points: Findings from a biographical narrative study. Social Work and Society, 12(1). Retrieved from http://www.socwork.net/sws/article/view/389/730

Polit, D. F., Morton, T. D., \& White, C. M. (1989). Sex, contraception and pregnancy among adolescents in foster care. Family Planning Perspectives, 21(5), 203. https://doi.org/10.2307/2135572

Pryce, J. M., \& Samuels, G. M. (2010). Renewal and risk: The dual experience of young motherhood and aging out of the child welfare system. Journal of Adolescent Research, 25(2), 205-230. https://doi.org/10.1177/0743558409350500

Reid, K., Flowers, P., \& Larkin, M. (2005). Exploring lived experience. The Psychologist, 18(1), 20-23.

Reilly, T. (2003). Transition from care: Status and outcomes of youth who age out of foster care. Child Welfare, 82(6), 727-746.

Rodermond, E., Kruttschnitt, C., Slotboom, A.-M., \& Bijleveld, C. C. (2016). Female desistance: A review of the literature. European Journal of Criminology, 13(1), 3-28. https://doi.org/10.1177/1477370815597251

Rowe, A. (2011). Narratives of self and identity in women's prisons: Stigma and the struggle for selfdefinition in penal regimes. Punishment \& Society, 13(5), 571-591. https://doi.org/10.1177/1462474511422151

Sermijn, J., Loots, G., \& Devlieger, P. (2005). In dialoog rond het zelf: van een modern Cartesiaans zelf naar alternatieve opvattingen rond zelfheid. Tijdschrift voor Familietherapie, 111(2), 117-153.

Sermijn, J. (2008). Ik in veelvoud. Een zoektocht naar de relatie tussen mens en psychiatrische diagnose. Leuven: Acco.

Shamai, M., \& Kochal, R.-B. (2008). "Motherhood starts in prison": the experience of motherhood among women in prison. Family Process, 47(3), 323-340. https://doi.org/10.1111/j.1545-5300.2008.00256.x

Sharpe, G. (2015). Precarious identities: "Young" motherhood, desistance and stigma. Criminology \& Criminal Justice, 15(4), 407-422. https://doi.org/10.1177/1748895815572163 
Sheridan, M. J. (1996). Comparison of the life experiences and personal functioning of men and women in prison. Families in Society: The Journal of Contemporary Human Services, 77(7), 423-434. https://doi.org/10.1606/1044-3894.942

Silva, J. M. (2012). Constructing adulthood in an age of uncertainty. American Sociological Review, 77(4), 502-522. https://doi.org/10.1177/0003122412449014

Smith, J. A., \& Osborn, M. (2008). Interpretative phenomenological analysis. In J. A. Smith (Ed.), Qualitative psychology: a practical guide to research methods (2nd ed., pp. 53-80). London: Sage.

Snacken, S. (2002). 'Normalisation' dans les prisons: concepts et défis. L'exemple de l'avant-project de loi pénitentiaire belge. In D. D. Schutter \& D. Kaminski (Eds.), L'institution du droit pénitentiaire. Enjeux de la reconnaissance de droits aux détenus (pp. 133-152). Paris: LGDJ-Bruylant.

Stas, K., Serrien, L., \& Van Menxel, G. (2008). Jongvolwassenen: tussen wal en schip? Berchem: Steunpunt Algemeen Welzijnswerk.

Stein, M., Ward, H., \& Courtney, M. (2011). Editorial: International perspectives on young people's transitions from care to adulthood. Children and Youth Services Review, 33(12), 2409-2411. https://doi.org/10.1016/j.childyouth.2011.08.012

Unrau, Y. A., Seita, J. R., \& Putney, K. S. (2008). Former foster youth remember multiple placement moves: a journey of loss and hope. Children and Youth Services Review, 30, 1256-1266. https://doi.org/10.1016/j.childyouth.2008.03.010

Van Audenhove, S. (2015). Overgang naar volwassenheid: belevingsonderzoek bij jongeren die de bijzondere jeugdbijstand verlaten. Unpublished dissertation, Universiteit Gent, Ghent.

Van Audenhove, S., \& Vander Laenen, F. (2011). Zorg voor de toekomst: jongeren uit de bijzondere jeugdzorg in de overgang naar volwassenheid. Vlaams Tijdschrift voor Orthopedagogie, 30(4), 16-28.

van der Geest, V., Bijleveld, C. \& Verbruggen, J. (2013). Vallen en opstaan. Mannen en vrouwen 17 jaar na vertrek uit een justitiële jeugdinrichting. Amsterdam: VU / NSCR.

Vander Laenen, F. (2008). Van hun kant bekeken: jongeren met gedrags- en emotionele stoornissen over de reactie op druggebruik in hun instelling. Tijdschrift voor Orthopedagogiek, Kinderpsychiatrie en Klinische Kinderpsychologie, 33(2), 65-77.

Van Menxel, G., Lescrauwaet, D., \& Parys, I. (2003). Verbinding verbroken: thuisloosheid en algemeen welzijnswerk. Berchem: Steunpunt Algemeen Welzijnswerk.

Verbruggen, J., Apel, R., van der Geest, V.R. \& Blokland, A. (2015). Work, income support, and crime in the Dutch welfare state: a longitudinal study following vulnerable youth into adulthood. Criminology, 53(4), 545-570. https://doi.org/10.1111/1745-9125.12080

Wilson, D. (2003). "Keeping quiet" or "going nuts": some emerging strategies used by young black people in custody at a time of childhood being re-constructed. The Howard Journal, 42(5), 411-425. https://doi.org/10.1046/i.1468-2311.2003.00297.x

Wilson, J. Z., \& Golding, F. (2016). Muddling upwards: The unexpected, unpredictable and strange on the path from care to high achievement in Victoria, Australia. In P. Mendes \& P. Snow (Eds.), Young people transitioning from out-of-home care: International research, policy and practice (pp. 135-154). London: Palgrave Macmillan. https://doi.org/10.1057/978-1-137-55639-4 7

Zeira, A., Arzev, S., Benbenishty, R. \& Portnoy, H. (2014). Children in educational residential care: A cohort study of Israeli youth, Australian Social Work, 67(1), 55-70. https://doi.org/10.1080/0312407X.2013.863956 